IRA-International Journal of Management \& Social Sciences

ISSN 2455-2267; Vol.04, Issue 01 (2016)

Institute of Research Advances

http://research-advances.org/index.php/RAJMSS

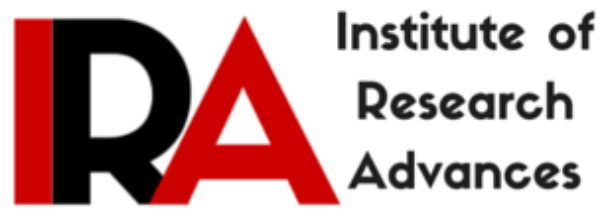

\title{
Relationship of Socio Economic Factors (SEF) and Energy Conservation Behavior in India: Empirical Study
}

\author{
${ }_{1}^{1}$ P B Suryawanshi, ${ }^{2}$ Dr. A G Jumle \\ ${ }^{1}$ Asst. Prof. PDVVPF's IBMRD, Savitribai Phule Pune University, Pune. \\ ${ }^{2}$ Professor, Zeal Education Society's ZIBACAR, Pune.
}

DOI: http://dx.doi.org/10.21013/jmss.v4.n1.p4

\section{How to cite this paper:}

Suryawanshi, P., \& Jumle, A. (2016). Relationship of Socio Economic Factors (SEF) and Energy Conservation Behavior in India: Empirical Study. IRAInternational Journal of Management \& Social Sciences (ISSN 2455-2267), 4(1). doi:http://dx.doi.org/10.21013/jmss.v4.n1.p4

(C) Institute of Research Advances

\section{(cc) EY-NC}

This works is licensed under a Creative Commons Attribution-Non Commercial 4.0 International License subject to proper citation to the publication source of the work.

Disclaimer: The scholarly papers as reviewed and published by the Institute of Research Advances (IRA) are the views and opinions of their respective authors and are not the views or opinions of the IRA. The IRA disclaims of any harm or loss caused due to the published content to any party. 


\begin{abstract}
In this research paper focus of the researcher is to study the effects of various socio economic factors on energy conservation level. This study discusses the energy conservation behaviors of rural and urban households and existence of barriers towards energy efficient appliances and effects of socio economic factors on energy related behaviors in the households located in Ahmednagar District, sample size was 567 households. The survey was conducted with help of structured questionnaire, and telephonic replies. Our result indicates that residence, education, religion and ownership of households are the major factors that have considerable effect on level of energy conservation behavior. We have tested hypothesis about all other factors and their relationships, an attempt has been made to predict the level of energy conservation by using multinomial logistic regression method. Particularly we want to find solution for questions like 'how socio economic factors play its role in determining energy demands?' 'What are the barriers for energy conservation?' 'Can we predict energy conservation behavior?'
\end{abstract}

Keywords: Energy conservation, Socio-economic Multinomial, Relationship, Empirical

\title{
Introduction-
}

In this study we have considered factors like age, gender, income, location, marital status, profession, education, No. of rooms, ownership of the house, field of study and religion.

Multinomial logistic regression was used for finding out the significant effect of independent variables on dependent variable which is energy conservation level measured in three levels as Low, Moderate and High.

In India residential sector contributed to $25 \%$ of the total electricity consumption in 2011. Lighting and major appliances like ceiling fans, televisions, refrigerators and air-conditioners account for about $80 \%$ of the residential electricity consumption. The rest comes from smaller and lesser used appliances like washing machine, geysers, computers etc.(NITI Aayog, 2015) Appliance ownership is significantly increasing both in rural and urban households due to rise in income levels and consumerism. The residential sector accounts for one-fifth of global energy consumption, resulting from the requirements to heat, cool, and light residential dwellings. It is therefore not surprising that energy efficiency in the residential market has gained importance in recent years. (Brounen, D., Kok, N., \& Quigley, J. M., 2013). In their study they examined the awareness, literacy and behavior of households with respect to their residential energy expenditures. They measured the extent to which consumers are aware of their energy consumption and whether they have taken measures to reduce their energy costs. They found that, consumer attitudes towards energy conservation, depends on the demographics but not energy literacy and awareness and have direct effects on behavior regarding heating and cooling of the home. Energy consumption in itself is not behavior, but it's a consequence of behaviors, such as turning the lights off or lowering thermostat levels (Becker et al. 1981). There is relationship between energy consumption level and income levels, Lifecycle stage and ethnicity have been identified (EIA 2009a; Hackett and Lutzenhiser 1991; Lutzenhiser 1993; O’Neill and Chen 2002). The root of modern prosperity can be found in the application of mass production technology, together with excess capital and a free market to exploit such technologies. This phenomenon is not favorable for sustainable development, of any economy. Developing countries like India need to save energy because it improves its global competitiveness and position in energy security.

\section{Review of Literature -}

Some of the relevant research work has been summarized, 
Fred A. Curtis et.al., 1984, this study assesses the influence of attitudinal and socio-economic factors on household energy conservation actions. A household interview survey in Regina, Saskatchewan found that respondents perceive an energy problem, although no association with energy conservation actions was determined. Two attitudinal and five socio-economic variables influenced household energy conservation.

Manfred Lenzen et.al., 2006,this paper is study of sustainable household consumption from a global perspective. Use per capita energy requirements as an indicator of environmental pressure focus on the importance of income growth in a cross-country analysis. It bring together family expenditure survey data, input-output tables, and energy statistics in a multivariate analysis

Eleni Sardianou, 2007, this paper develops an empirical model to investigate the main determinants of household energy conservation patterns in Greece employing cross-section data. In the empirical analysis, household energy-conserving choices models are employed, using a discrete and a latent trait variable respectively as a dependent variable. The results show that socio-economic variables such as consumers' income and family size are suitable to explain differences towards energy conservation preferences. In addition, the results suggest that electricity expenditures and age of the respondent are negatively associated with the number of energy-conserving actions that a consumer is willing to adopt.

Wokje Abrahamse, Linda Steg, 2009, the study examined the relative importance of socio-demographic variables and psychological variables in relation to household energy use and changes in energy use. Results indicate that energy use is determined by socio-demographic variables, whereas changes in energy use, which may require some form of (cognitive) effort, appear to be related to psychological variables.

Eva Heiskanen et. al., 2010, paper analyses different types of emerging low-carbon communities as a context for individual behavioural change. The focus is on how these communities offer solutions to problems in previous attempts to change individual behaviour. These problems include social dilemmas, social conventions, socio-technical infrastructures and the helplessness of individuals. Different community types are examined, including geographical communities as well as sector-based, interestbased and smart mob communities.

John Thøgersen, Alice Grønhøj, 2010, the results suggest two approaches to promote electricity saving in households, first to change the socio-structural environment to be more facilitating for energy saving and empower householders to be more effective in their striving towards this goal through improved feedback about their household's electricity consumption and second social norms marketing, communicating social expectations and others' successful electricity saving achievements.

Geun Young Yun, Koen Steemers, 2011, as global warming continues, the current trend implies that the uptake of air conditioning in the residential sector will go up, thus potentially increasing domestic cooling energy consumption. In this context, this paper investigates the significance of behavioural, physical and socio-economic parameters on cooling energy in order to improve energy efficiency in residential buildings. It demonstrates that such factors exert a significant indirect as well as direct influence on energy use, showing that it is particularly important to understand indirect relationships.

Steg Linda, 2008, In this study barriers to energy conservation are discussed, they are insufficient knowledge of effective ways to reduce household energy use, the low priority and high costs of energy savings, and the lack of feasible alternatives, the paper elaborates on the effectiveness and acceptability of strategies aimed to promote household energy savings. Informational strategies aimed at changing individuals' knowledge, perceptions, cognitions, motivations and norms, as well as structural strategies aimed at changing the context in which decisions are made, are also discussed. 
The concept of energy efficiency is broadly used in the fields of energy, economics, and environment, and what is more has had emerged as one of the most cost-effective methods in conserving and saving energy and lessening emissions of greenhouse gas. Studies have confirmed both in quantitative and qualitative results (Yang et al, 2014). However, the market penetration of energy efficient technologies is generally hindered by barriers that are effected by prices, financing, international trade, structure of market institutions, information provision and socio-cultural and behavioral issues. There are other barriers in the forms of convenience and inertia of the status quo that forces solution providers technology providers developing energy conservation devices, leading to persistent high energy consuming appliances in both urban and rural households (Ramesh, Khan,2013).

\section{Objectives:-}

The aim of this study is to conduct in-depth analysis of relationship of socio economic factors and the level of energy conservation behavior in urban and rural households, also wants to identify what are the barriers to efficient energy use among rural and urban households in India.

Following are the research objectives,

1. To evaluate the effect of socio economic factors on energy conservation practice.

2. To identify the barriers to efficient energy use in the households.

3. To predict energy conservation behavior

\section{Methodology-}

Research Method- Quantitative

Design- Descriptive \& Exploratory

For Primary data- collected from households situated in the area under study.

Questionnaire Method -Semi structured questions for Survey. Personal Interviews -Direct and Telephonic, Observations, Expert Opinion from head of households.

Questionnaire method:

A schedule (questionnaire) was used as a research instrument to collect primary data. The schedule consists of combination of open and close ended questions. Five point and Seven point Likert scale are used to record the responses.

For Secondary data -

CMIE database, TERI reports, Bureau of Energy Efficiency reports. Bureau of Energy Efficiency reports, PCRA study reports. NCAER Reports, Ministry of Power, UNO papers, Research Papers published in referred journals, MEDA study reports.

For Data Analysis -

Testing the Hypothesis- Chi square, Multinomial Logistic regression with Software: SPSS 18.00

Sample Design

Sampling Method: Sampling design was prepared so as to draw a representative sample from the population and reach reliable conclusions.

Universe- $\quad$ Households in Ahmednagar District.

Sample frame- $\quad$ Housing profile census 2011 (Govt. of India) 
Sample Unit-

Households

Defined-

Rural area as- population below 7000 \& Urban $>7000$

Type of sampling - Probability type, multistage sampling, area sampling plan

Sample size-

567 households

\begin{tabular}{|c|c|c|c|c|}
\hline \multicolumn{5}{|c|}{ Table No.01- DEMOGRAPHIC DETAILS } \\
\hline & & \multicolumn{2}{|c|}{ Location } & \multirow[b]{3}{*}{ Total } \\
\hline & & Rural & Urban & \\
\hline & & Count & Count & \\
\hline \multirow[t]{2}{*}{ gender } & male & 394 & 94 & 488 \\
\hline & female & 39 & 40 & 79 \\
\hline \multirow[t]{2}{*}{ marital status } & married & 380 & 115 & 495 \\
\hline & unmarried & 53 & 19 & 72 \\
\hline \multirow[t]{5}{*}{ age of respondent } & $18-29$ & 78 & 29 & 107 \\
\hline & $30-39$ & 140 & 55 & 195 \\
\hline & $40-49$ & 135 & 40 & 175 \\
\hline & $50-59$ & 57 & 9 & 66 \\
\hline & above $60 \mathrm{yr}$ & 23 & 1 & 24 \\
\hline \multirow[t]{5}{*}{ religion } & hindu & 304 & 120 & 424 \\
\hline & muslim & 30 & 6 & 36 \\
\hline & christian & 8 & 3 & 11 \\
\hline & buddhist & 54 & 4 & 58 \\
\hline & others & 37 & 1 & 38 \\
\hline \multirow{5}{*}{$\begin{array}{l}\text { total members } \\
\text { staying in the } \\
\text { household }\end{array}$} & 1-2 members & 38 & 7 & 45 \\
\hline & 3-4 members & 240 & 103 & 343 \\
\hline & 5-6 members & 107 & 18 & 125 \\
\hline & 7-8 members & 42 & 5 & 47 \\
\hline & More than 8 & 6 & 1 & 7 \\
\hline \multirow{5}{*}{$\begin{array}{l}\text { profession of the } \\
\text { respondent }\end{array}$} & farmer & 126 & 4 & 130 \\
\hline & pvt-service & 135 & 75 & 210 \\
\hline & business & 64 & 22 & 86 \\
\hline & govt. service & 13 & 8 & 21 \\
\hline & others & 95 & 25 & 120 \\
\hline \multirow{5}{*}{$\begin{array}{l}\text { monthly income of } \\
\text { households }\end{array}$} & Less than 5000 & 285 & 20 & 305 \\
\hline & $5000-10000$ & 112 & 47 & 159 \\
\hline & $10001-30000$ & 31 & 41 & 72 \\
\hline & $30001-50000$ & 2 & 22 & 24 \\
\hline & More than 50000 & 3 & 4 & 7 \\
\hline \multirow{5}{*}{$\begin{array}{l}\text { number of rooms in } \\
\text { house }\end{array}$} & $1-2$ rooms & 225 & 50 & 275 \\
\hline & 3-4 rooms & 181 & 74 & 255 \\
\hline & $5-6$ rooms & 26 & 8 & 34 \\
\hline & $7-8$ rooms & 0 & 1 & 1 \\
\hline & More than 8 rooms & 1 & 1 & 2 \\
\hline \multirow[t]{2}{*}{ ownership of house } & owner & 386 & 101 & 487 \\
\hline & on rent & 46 & 30 & 76 \\
\hline
\end{tabular}




\begin{tabular}{|c|c|c|c|c|}
\hline & other & 1 & 3 & 4 \\
\hline \multirow{5}{*}{$\begin{array}{l}\text { monthly bill of } \\
\text { electricity }\end{array}$} & Rs 50-100 & 186 & 4 & 190 \\
\hline & Rs $101-300$ & 185 & 27 & 212 \\
\hline & Rs $301-500$ & 44 & 56 & 100 \\
\hline & Rs 501-1000 & 14 & 40 & 54 \\
\hline & Rs $1001-3000$ & 4 & 7 & 11 \\
\hline \multirow{5}{*}{$\begin{array}{l}\text { education of the } \\
\text { respondent }\end{array}$} & SSC & 89 & 24 & 113 \\
\hline & HSC & 59 & 21 & 80 \\
\hline & DEGREE & 34 & 44 & 78 \\
\hline & PG & 20 & 32 & 52 \\
\hline & Others & 231 & 13 & 244 \\
\hline \multirow{6}{*}{$\begin{array}{l}\text { field of study at } \\
\text { graduation }\end{array}$} & arts & 71 & 29 & 100 \\
\hline & commerce & 29 & 23 & 52 \\
\hline & science & 21 & 36 & 57 \\
\hline & engineering & 3 & 9 & 12 \\
\hline & Others & 309 & 37 & 346 \\
\hline & Total & 433 & 134 & 567 \\
\hline
\end{tabular}

\section{Data Analysis and Results-}

"To evaluate the effect of socio economic factors on energy conservation practice"

The multinomial logistic regression was performed to test the effect of socio economic factors on energy conservation level and for predicting the energy conservation level of lower saver, moderate or higher saver with reference to SEF factors.

Result: Multinomial logistic regression was conducted with dependent variable with three categories of energy conservation level for 567 households. We can also study the association of socio economic factors with the conservation level. After studying this phenomenon, it is observe that independent variables -resident, religion, education, ownership have significant associations with energy conservation level.

After applying multinomial logistic regression, the model fitting shows as per Table No. 02 and 03, it is significant (Sig. value < 0.000), also the model can explain $23.8 \%$ variance (Nagelkerke). Overall prediction accuracy is $60.3 \%$. Null hypothesis is "regression coefficients are equal to zero" The table of parameter estimates explains the odds ratio $\operatorname{Exp}(\mathrm{B})$ for the dependent variable energy conservation level. The odds ratio for household with religion (Hindu) has 16.11 times, likelihood of coming in higher category over lower category; it is significant association with $\mathrm{OR}>1$. The odds ratio is 17.3 times for Buddhist to be in higher category over lower with it is significant association with $O R>1$. The odds ratio for household with location (rural) has 3.5 times, likelihood of not coming in higher category over lower category; it is OR<1. The odds ratio for household with education (PG) has 4.9 times, likelihood of coming in higher category over lower category; it is significant association with OR $>1$. The odds ratio for household with religion (Muslim) has 7.2 times, likelihood of coming in higher category over lower category; it is significant association with $\mathrm{OR}>1$. The odds for households with profession of head of household (business) have 2.04 times likelihood of coming in higher category over lower, it is not significant with OR>1.

\begin{tabular}{|l|l|l|l|l|l|l|}
\hline \multicolumn{4}{|l|}{ Table No.02- Model Fitting Information } \\
\hline Model & \multicolumn{4}{l|}{ Model Fitting Criteria } & Likelihood Ratio Tests \\
\cline { 2 - 7 } & & BIC Log & $\begin{array}{l}-2 \\
\text { Likelihood }\end{array}$ & Chi-Square & df & Sig. \\
\hline Intercept Only & 545.058 & 553.738 & 541.058 & & & \\
\hline
\end{tabular}


IRA-International Journal of Management \& Social Sciences

\begin{tabular}{|l|l|l|l|l|l|l|}
\hline Table No.02- Model Fitting Information \\
\hline \multirow{2}{*}{ Model } & Model Fitting Criteria & Likelihood Ratio Tests \\
\cline { 2 - 7 } & AIC & BIC & $\begin{array}{l}-2 \\
\text { Likelihood }\end{array}$ & Chi-Square & df & Sig. \\
\hline Intercept Only & 545.058 & 553.738 & 541.058 & & & \\
\hline Final & 474.481 & 613.372 & 410.481 & 130.577 & 30 & .000 \\
\hline
\end{tabular}

\begin{tabular}{|c|c|c|c|c|c|c|c|c|c|}
\hline \multicolumn{9}{|c|}{ Table No.03-Parameter Estimates } & \multirow{3}{*}{ Sig. } \\
\hline \multicolumn{2}{|c|}{$\begin{array}{l}\text { Dependent three categories } \\
\text { of Energy Conservation Level } \\
\text { 1-Low, 2-Moderate, 3- High }\end{array}$} & \multirow[t]{2}{*}{$\mathrm{B}$} & \multirow[t]{2}{*}{ Wald } & \multirow[t]{2}{*}{ df } & \multirow[t]{2}{*}{ Sig. } & \multirow[t]{2}{*}{$\operatorname{Exp}(B)$} & \multicolumn{2}{|c|}{$\begin{array}{l}95 \% \\
\text { Confidence } \\
\text { Interval for } \\
\operatorname{Exp}(B)\end{array}$} & \\
\hline & & & & & & & $\begin{array}{l}\text { Lower } \\
\text { Bound }\end{array}$ & \begin{tabular}{|l|} 
Upper \\
Bound \\
\end{tabular} & \\
\hline HIGH & [ownership=1] & -16.429 & 1592.693 & 1 & .000 & .000 & .000 & .000 & $*$ \\
\hline HIGH & Intercept & 15.050 & 251.006 & 1 & .000 & & & & $*$ \\
\hline HIGH & {$[$ religion $=1]$} & 2.780 & 12.380 & 1 & .000 & 16.113 & 3.425 & 75.795 & $*$ \\
\hline HIGH & [religion $=4]$ & 2.849 & 11.121 & 1 & .001 & 17.265 & 3.236 & 92.103 & $*$ \\
\hline HIGH & {$[$ resident $=1]$} & -1.255 & 6.697 & 1 & .010 & .285 & .110 & .738 & $*$ \\
\hline HIGH & [education $=4$ ] & 1.591 & 5.238 & 1 & .022 & 4.910 & 1.257 & 19.183 & $*$ \\
\hline HIGH & [religion=2] & 1.984 & 4.193 & 1 & .041 & 7.271 & 1.089 & 48.558 & $*$ \\
\hline HIGH & [education $=2$ ] & -.727 & 2.849 & 1 & .091 & .483 & .208 & 1.124 & ns \\
\hline HIGH & [profession=3] & .713 & 2.217 & 1 & .136 & 2.039 & .798 & 5.211 & ns \\
\hline HIGH & [education $=1$ ] & -.539 & 1.916 & 1 & .166 & .584 & .272 & 1.251 & ns \\
\hline HIGH & [profession=1] & .584 & 1.795 & 1 & .180 & 1.793 & .763 & 4.212 & ns \\
\hline HIGH & [education $=3$ ] & .552 & 1.187 & 1 & .276 & 1.737 & .643 & 4.693 & ns \\
\hline MODERATE & [religion=1] & 1.890 & 19.426 & 1 & .000 & 6.619 & 2.856 & 15.338 & $*$ \\
\hline MODERATE & {$[$ resident $=1]$} & -1.557 & 12.593 & 1 & .000 & .211 & .089 & .498 & $*$ \\
\hline MODERATE & [religion=2] & 1.885 & 10.386 & 1 & .001 & 6.586 & 2.093 & 20.726 & $*$ \\
\hline MODERATE & [religion $=4$ ] & 1.031 & 3.727 & 1 & .054 & 2.803 & .984 & 7.978 & ns \\
\hline MODERATE & [religion $=3$ ] & 1.244 & 2.273 & 1 & .132 & 3.471 & .688 & 17.500 & $\mathrm{~ns}$ \\
\hline MODERATE & [education $=2$ ] & -.467 & 1.779 & 1 & .182 & .627 & .316 & 1.245 & ns \\
\hline
\end{tabular}

"Energy Conservation level is depends on socio economic factors of households"

We are using Chi-square test for identifying relationship between socio economic factors and the energy conservation level.

H1 (null): There is no significant relationship between energy conservation level and socio economic factors

H1: There is a significant relationship between energy conservation level and socio economic factors

Dependent Variable: Energy conservation level (1= Lower, 2=Moderate, 3= Higher)

Independent variables: Socio economic factors

Table No.04- Relationship of ECL and SEF

\begin{tabular}{l|l|l|}
\hline Variable & Lower saver & Moderate \\
\hline
\end{tabular}

\begin{tabular}{l|l} 
Moderate & Higher saver
\end{tabular}

Chi

Sig. 
IRA-International Journal of Management \& Social Sciences

\begin{tabular}{|c|c|c|c|c|c|c|}
\hline & & & & $\begin{array}{l}\text { square } \\
\text { (df) }\end{array}$ & value & \\
\hline Gender & $\begin{array}{l}\text { Male }=20.9 \% \\
\text { Female }=13.9 \%\end{array}$ & $\begin{array}{l}\text { Male }=55.5 \% \\
\text { Female }=49.4 \%\end{array}$ & $\begin{array}{l}\text { Male }=23.6 \% \\
\text { Female }=36.7 \%\end{array}$ & $\begin{array}{l}(2, \\
N=567) \\
=6.759\end{array}$ & 0.034 & $*$ \\
\hline Marital & $\begin{array}{l}\text { Married }=21.4 \% \\
\text { Unmarried }=9.7 \%\end{array}$ & $\begin{array}{l}\text { Married }=54.5 \% \\
\text { Unmarried }=55.6 \%\end{array}$ & $\begin{array}{l}\text { Married =24\% } \\
\text { Unmarried } \\
=34.7 \%\end{array}$ & $\begin{array}{l}(2, \\
N=567) \\
=7.14\end{array}$ & 0.028 & $*$ \\
\hline Location & $\begin{array}{l}\text { Rural }=24.2 \% \\
\text { Urban }=6.0 \%\end{array}$ & $\begin{array}{l}\text { Rural }=52.2 \% \\
\text { Urban }=62.7 \%\end{array}$ & $\begin{array}{l}\text { Rural }=23.6 \% \\
\text { Urban }=31.3 \%\end{array}$ & $\begin{array}{l}(2, \\
N=567) \\
=21.6\end{array}$ & 0.000 & $*$ \\
\hline Age & $\begin{array}{l}\text { Above } 60=25.0 \% \\
18-29=11.2 \%\end{array}$ & $\begin{array}{l}50-59=62.1 \% \\
30-39=51.8 \%\end{array}$ & $\begin{array}{l}18-29=30.8 \% \\
50-59=19.7 \%\end{array}$ & $\begin{array}{l}(8, \\
N=567) \\
=11.0\end{array}$ & 0.2 & $\overline{\mathrm{ns}}$ \\
\hline Religion & $\begin{array}{l}\text { Others }=65.8 \% \\
\text { Hindu }=14.6 \%\end{array}$ & $\begin{array}{l}\text { Muslim }=66.7 \% \\
\text { Other }=28.9 \%\end{array}$ & $\begin{array}{l}\text { Buddhist }=34.5 \% \\
\text { Hindu }=27.4 \%\end{array}$ & $\begin{array}{l}(8, \\
N=567) \\
=69.3\end{array}$ & 0.000 & $*$ \\
\hline $\begin{array}{l}\text { Members in } \\
\text { house }\end{array}$ & $\begin{array}{l}5-6=23.2 \% \\
\text { More than } 8=0 \%\end{array}$ & $\begin{array}{l}>\text { than } 8=85.7 \% \\
5-6=49.6 \%\end{array}$ & $\begin{array}{l}5-6=27.2 \% \\
>\text { than } 8=14.3 \%\end{array}$ & $\begin{array}{l}(8, \\
N=567) \\
=9.3\end{array}$ & 0.315 & $\overline{\mathrm{ns}}$ \\
\hline Profession & $\begin{array}{l}\text { Others }=30.0 \% \\
\text { Pvt } \\
\text { Service }=15.7 \%\end{array}$ & $\begin{array}{l}\text { Pvt serv }=57.6 \% \\
\text { GovServ }=47.6 \%\end{array}$ & $\begin{array}{l}\text { Govt serv }=28.6 \% \\
\text { Others }=19.2 \%\end{array}$ & $\begin{array}{l}(8, \\
N=567) \\
=11.8\end{array}$ & 0.161 & $\mathrm{~ns}$ \\
\hline Income & $\begin{array}{l}<5000=23.6 \% \\
>50000=0 \%\end{array}$ & $\begin{array}{l}5000-10000=59.7 \% \\
>50000=28.6 \%\end{array}$ & $\begin{array}{l}>50000=71.4 \% \\
5000- \\
10000=20.8 \%\end{array}$ & $\begin{array}{l}(8, \\
N=567) \\
=25.7\end{array}$ & 0.001 & $*$ \\
\hline $\begin{array}{l}\text { No of } \\
\text { rooms }\end{array}$ & $\begin{array}{l}>8 \text { rooms }=50 \% \\
7-8 \text { rooms }=0 \%\end{array}$ & $\begin{array}{l}7-8 \text { rooms }=100 \% \\
>8 \text { rooms }=0 \%\end{array}$ & $\begin{array}{l}>8 \text { rooms }=50 \% \\
7-8 \text { rooms }=0 \%\end{array}$ & $\begin{array}{l}8, \mathrm{~N}=567) \\
=23\end{array}$ & 0.003 & $*$ \\
\hline Ownership & $\begin{array}{l}\text { Rent }=32.9 \% \\
\text { Owner }=18.1 \%\end{array}$ & $\begin{array}{l}\text { Owner }=56.1 \% \\
\text { Rent }=48.7 \%\end{array}$ & $\begin{array}{l}\text { Owner }=25.9 \% \\
\text { Rent }=18.4 \%\end{array}$ & $\begin{array}{l}(4, \\
N=567) \\
=21.17\end{array}$ & 0.000 & $*$ \\
\hline $\begin{array}{l}\text { Monthly } \\
\text { Bill } \\
\text { electricity }\end{array}$ & $\begin{array}{l}100-300=26.4 \% \\
>1000=0 \%\end{array}$ & $\begin{array}{l}50-100=57.4 \% \\
501-1000=51.9 \%\end{array}$ & $\begin{array}{l}1001-3000=45.5 \% \\
50-100=22.6 \%\end{array}$ & $\begin{array}{l}(8, \\
N=567) \\
=20.2\end{array}$ & 0.010 & $*$ \\
\hline Education & $\begin{array}{l}\mathrm{HSC}=25 \% \\
\text { Degree }=11.5 \%\end{array}$ & $\begin{array}{l}\mathrm{SSC}=61.9 \% \\
\mathrm{PG}=38.5 \%\end{array}$ & $\begin{array}{l}\mathrm{PG}=55.8 \% \\
\mathrm{SSC}=17.7 \%\end{array}$ & $\begin{array}{l}(8, \\
N=567) \\
=41.3\end{array}$ & 0.000 & $*$ \\
\hline $\begin{array}{l}\text { Field of } \\
\text { education }\end{array}$ & $\begin{array}{l}\text { Arts }=24.4 \% \\
\text { Engg }=8.3 \%\end{array}$ & $\begin{array}{l}\text { Engg }=66.7 \% \\
\text { Arts }=50.0 \%\end{array}$ & $\begin{array}{l}\text { Science }=42.1 \% \\
\text { Others }=21.1 \%\end{array}$ & $\begin{array}{l}(8, \\
N=567) \\
=18.9\end{array}$ & 0.015 & $*$ \\
\hline
\end{tabular}

Source: Primary data

From Table No.04, as per analysis of data using chi-square for independence, the variables Location, gender, marital status, religion, Income, No of rooms, ownership, monthly bill of electricity, education and field of education have significant association with the energy conservation level. Variables like Age, Members in house, Profession does not associated with energy conservation level 
Result: Null hypothesis is rejected, which means socio economic factors have relationship with level of energy conservation.

\section{Conclusion and Scope for further research -}

Some factors like socio economic factors, behavioral factors, market conditions and government policies are associated with household's level of energy conservation. It was observed that, urban households have shown positive behavior towards energy conservation, than rural households. Barriers are prominent in case of urban households because they do not want to compromise on level of comfort; do not like to change the behavior, not worried about consequences. As per analysis of data for testing association between socio economic status and energy conservation behavior, we found that the variables like location, gender, marital status, and religion, Income, number of rooms, ownership, and monthly bill of electricity, education and field of education have significant association with the energy conservation level. But some variables like age, number of members in the house, profession of the head of household does not associated with the energy conservation level. Understating consumer behavior is one of the difficult fields of research, in that study of energy conservation behavior is even more complex. The difficulties faced while determining and finalizing the factors, which have some impact on our energy conservation behavior. There are two methods we can implement to minimize the use of energy in household, one is curtailment of the energy wastage while using it, it is basically related to the individual consumer behavior which is affected by sociological and psychological factors. It depends on habits like turning off lights, fans on a frequent basis in the household while not allowing any kind of energy wastages. Another method is the use of energy efficient appliances and improvement of efficiency of energy use through technological improvement, up gradation and it requires investments in energy efficient devices. Since energy conservation is the most cost effective solution for economic development of a nation in sustainable way, further studies can focus on estimating actual monetary benefits of pro environmental behaviors.

\section{Acknowledgement}

This research was supported by the University Grants Commission, New Delhi at IndSearch centre Pune.

\section{References-}

1. [EIA] Energy Information Administration. 2009a. Residential Energy Consumption Survey 2005 (microdata).

2. Hackett, B., Lutzenhiser, L. 1991. "Social Structures and Economic Conduct: InterpretingVariations in Household Energy Consumption." Sociological Forum 6: 449-70.

3. O'Neill, B.C., and B. S. Chen. 2002. "Demographic Determinants of Household Energy Use in the United States." Population and Development Review 28:53-88.

4. Fred A. Curtis, P. Simpson-Housley, S. Drever, 1984, Communications on energy Household energy conservation ,Energy Policy, Volume 12, Issue 4, Pages 452-456

5. Eva Heiskanen, Mikael Johnson, Simon Robinson, Edina Vadovics, Mika Saastamoinen, 2010, Low-carbon communities as a context for individual behavioural change, Energy Policy, Volume 38, Issue 12, Pages 7586-7595

6. Eleni Sardianou, 2007, Estimating energy conservation patterns of Greek households, Energy Policy, Volume 35, Issue 7, Pages 3778-3791 
7. Wokje Abrahamse, Linda Steg, 2009, How do socio-demographic and psychological factors relate to households' direct and indirect energy use and savings?, Journal of Economic Psychology, Volume 30, Issue 5, Pages 711-720

8. John Thøgersen, Alice Grønhøj,2010, Electricity saving in households-A social cognitive approach, Energy Policy, Volume 38, Issue 12, Pages 7732-7743

9. A. Druckman, P. Sinclair, T. Jackson, 2008, A geographically and socio-economically disaggregated local household consumption model for the UK, Journal of Cleaner Production, Volume 16, Issue 7, Pages 870-880

10. Manfred Lenzen, Mette Wier, Claude Cohen, Hitoshi Hayami, Shonali Pachauri, Roberto Schaeffer, 2006, A comparative multivariate analysis of household energy requirements in Australia, Brazil, Denmark, India and Japan , Energy, Volume 31, Issues 2-3, Pages 181-207

11. Brounen, D., Kok, N., \& Quigley, J. M. (2013). Energy literacy, awareness, and conservation behavior of residential households. Energy Economics, 3842-50.

doi:10.1016/j.eneco.2013.02.008

12. Becker L. J., Seligman C., Fazio R. H. \& Darley J. M. (1981) Relating Attitudes to Residential Energy Use. Environment and Behavior Vol. 13: 590-609.

13. Yang, M. et al(2014), GEF Experiences in Closing the Global Energy Efficiency Gap, Low Carbon Economy, 2014, 5, 6-1

14. Ramesh, S. P. and Khan, E.(2013), Energy Scenario and Energy Efficiency: Programme and Policies of Booming India, American International Journal of Research in Science, Technology, Engineering \& Mathematics, 3(2), 199-207.

15. Yun, Geun Young \& Steemers, Koen, 2011. "Behavioural, physical and socio-economic factors in household cooling energy consumption," Applied Energy, Elsevier, vol. 88(6), pages 21912200

16. Steg, Linda, 2008. "Promoting household energy conservation," Energy Policy, Elsevier, vol. 36(12), pages 4449-4453, December. 